\title{
Analisis Implementasi Kartu Kredit Syariah Pada PT. Bank BNI Syariah Cabang Palu Perspektif Ekonomi Islam
}

\author{
Dharma Kharini Abd Haling ${ }^{*}$, Uswatun Hasanah ${ }^{2}$, Nuriatullah Nuriatullah ${ }^{3}$, Noor Riefma Hidayah ${ }^{3}$ \\ ${ }^{1}$ Jurusan Perbankan, Fakultas Ekonomi dan Bisnis Islam, IAIN Palu \\ ${ }^{2}$ Jurusan Perbankan, Fakultas Ekonomi dan Bisnis Islam, IAIN Palu \\ ${ }^{3}$ Jurusan Perbankan, Fakultas Ekonomi dan Bisnis Islam, IAIN Palu
}

ABSTRAK

Kebutuhan akan kartu kredit saat ini dipengaruhi oleh dua faktor, yaitu: Pertama, Keunggulan; Praktis, adanya diskon khusus dan reward. Kedua, Kemudahan, Memiliki cadangan uang, fasilitas dan kemudahan dan bisa beli sekarang bayar kemudian. Bank BNI menjadi bank milik negara pertama yang mengeluarkan kartu kredit syariah. Kartu kredit Hasanah Card merupakan salah satu produk yang dikeluarkan bank Syariah dan memberikan inovasi baru bagi dunia perbankan Islam di Inonesia. Ditinjau dari aspek hukum, Hasanah Card payung hukumnya berasal dari Fatwa DSN No. 54/DSN-MUI/X/2006. Sebagaimana dalam Bank BNI Syariah menyebutkan produk ini terdiri dari tiga akad, yaitu: Kafalah, Qardh, dan Ijarah. Penelitian ini betujuan untuk menganalisis impelentasi kartu kredit yariah yang ada pada PT. Bank BNI Syariah cabang Palu, serta implementasinya kartu kredit syariah yang ada pada PT. Bank BNI Syariah dari segi perspektif ekonomi islam. Metode penelitian yang digunakan adalah kualitatif. Dalam penelitian ini, data yang diperoleh dari dokumentasi, observasi, serta wawancara langsung dengan pihak bank.
INFORMASI

ARTIKEL
Kata kunci:

Implementasi, Kartu

Kredit, BNI Syariah,

Ekonomi Islam 


\section{PENDAHULUAN}

Di Indonesia pelopor Perbankan syariah adalah Bank Muamalat Indonesia, berdiri pada tahun 1991 dan bank ini diprakarsai oleh Majelis Ulama Indonesia (MUI) dan pemerintah serta dukungan dari ikatan cendekiawan Muslim Indonesia (ICMI) adalah beberapa pengusaha muslim. ${ }^{1}$

Bank Muamalat Indonesia sempat mengalami masalah akibat imbas dari krisis moneter pada akhir tahun90-an sehingga pendapatannya hanya sepertiga dari modal awal. Namun, saat itu BMI mendapatkan suntikan dana dari IDB sehingga pada periode 1999-2002 dapat bangkit kembali dan menghasilkan laba. Keberadaan bank Syariah di Indonesia telah diatur dalam Undang-Undang Nomor 10 Tahun 1998 tentang perubahan UndangUndang Nomor 7 Tahun 1992 tentang Perbankan. ${ }^{2}$

Kemudian, pada tahun 1999 disahkan UU No.23 tahun 1999 tentang Bank Indonesia, bahwa Bank Indonesia dapat melakukan pengendalian moneter berdasarkan prinsis-prinsip Syariah. ${ }^{3}$

Undang-Undang No 10 Tahun 1999 dan Undang-Undang no 23 Tahun 1999 selanjutnya menjadi dasar hukum bagi keberadaan dua sistem perbankan (konvensional dan syariah) secara

\footnotetext{
${ }^{1}$ Santoso dan Sulhadi, Periodisasi Perkembangan Hukum Perbankan Syariah di Indonesia, Yudisia, Vol.6, No. 1, Juni 2015. 121.

${ }^{2}$ Ibid, hal. 122.

${ }^{3}$ Ali Syokron, Dinamika Perkembangan Perbankan Syariah di Indonesia, Jurnal Ekonomi dan Hukum Islam, Vol.3, No.2, 2013, 29.
}

berdampingan dalam memberikan pelayanan jasa perbankan bagi masyarakat.

Dalam masalah perekonomian, setiap waktu mengalami perkembangan termasuk pada perbankan syariah. Sejak tahun 2000-an perbankan syariah di Indonesia mulai berkembang, dan perkembangan tersebut diiringi dengan munculnya beberapa produk baru, termasuk kartu kredit syariah. Selanjutnya, industri perbankan syariah telah mengalami perkembangan yang pesat dan memiliki landasan hukum yang memadai yakni dengan diterbitkannya Undang-Undang No. 21 Tahun 2008 tentang Perbankan Syariah. $^{4}$

Kebutuhan akan kartu kredit saat ini dipengaruhi oleh dua faktor, yaitu ${ }^{5}$ : Pertama, Keunggulan; Praktis, adanya diskon khusus dan reward. Kedua, Kemudahan, Memiliki cadangan uang, fasilitas dan kemudahan dan bisa beli sekarang bayar kemudian.

Dalam penggunaan kartu kredit syariah, kita bisa mendapatkan manfaat, yaitu ${ }^{6}$; a) Menjadi lebih hemat. Dalam sistem penggunaan kartu kredit syariah memiliki batasan yang harus dipenuhi ketika menggunakannya, dan itu mengacu pada Fatwa DSN No.54/DSN-MUI/x/2006. Batasan tersebut salah satunya adalah agar tidak memicu pengeluaran yang berlebihan

${ }^{4}$ Ibid, ha 1. 31.

${ }^{5}$ Risna Sulistyawaty, Perilaku Konsumen dalam Penggunaan Kartu Kredit di Wilayah DKI Jakarta, Artikel. 7.

${ }^{6}$ Reni Widya Astari, https://kreditgogo.com/artikel/Kartukredit/keuntungan-memiliki-kartu-kreditsyariah.html. 
atau dikenal dengan sebutan Israf. b) Tidak ada sistem bunga. Kartu kredit syariah tidak menerapkan sistem bunga, bank penerbit kartu kredit syariah biasanya hanya menerima fee (ujrah kafalah) sesuai perjanjian atau akad dengan nasabah pemegang kartu. c) Tidak ada bunga keterlambatan. Biasanya dalam kartu kredit akan di kenakan denda. Namun dalam kartu kredit syariah denda ditarik dari biaya penagihan bank serta jumlah presentase tertentu dari tagihan. d) Bisa beramal. Biaya denda yang dibayarkan nasabah akibat keterlambatan membayar tagihan tidak menjadi hak bank penerbit kartu. Denda itu dialihkan kearah sektor-sektor sosial. Ini akan menjadi kebijakan atau Qardhul Hasan yang langsung amal yang telah ditunjuk. e) Biaya Administrasi di Merchant lebih rendah. Besarnya fee yang dikenakan didasarkan pada nilai transaksi, sehingga bersifat fluktuatif.

Bank BNI menjadi bank milik negara pertama yang mengeluarkan kartu kredit syariah. Kartu kredit Hasanah Card merupakan salah satu produk yang dikeluarkan bank Syariah dan memberikan inovasi baru bagi dunia perbankan Islam di Inonesia. Ditinjau dari aspek hukum, Hasanah Card paying hukumnya berasal dari Fatwa DSN No. 54/DSN-MUI/X/2006.
Sebagaimana dalam situs resmi BNI Syariah menyebutkan produk ini terdiri dari tiga akad, yaitu: Kafalah, Qardh, dan Ijarah. ${ }^{7}$ Dan penggunaaan katu kredit tersebut hanya dapat di guanakan untuk transaksi yang sesuai dengan Syariah.

Seiring dengan perkembangan perbankan di Indonesia, maka perbankan yang berbasis syariah yang lebih Islami ditawarkan kepada masyarakat dengan memberikan layanan bebas bunga kepada para nasabahnya. Pembayaran dan penarikan bunga dilarang dalam semua bentuk transaksi. Islam melarang kaum muslim menarik atau membayar bunga (riba). Pelarangan inilah yang membedakan perbankan Islam (Syariah) dengan perbankan konvensional.

Kehadiran kartu kredit syariah ini dianggap sebagai sebuah jalan keluar atas keresahan masyarakat dengan praktik bunga yang diterapkan dalam produk kartu kredit dari bank konvensional. Selain itu, adanya kartu kredit syariah dapat menjadi alternatif bagi masyarakat yang beragama Islam sebagai pengganti kartu kredit yang menggunakan sistem bunga dalam operasionalnya.

Alasan penulis mengangkat judul ini karena berdasarkan jurnal penelitian oleh Indah Nuhyatia, berjudul kajian fiqh dan 
perkembangan kartu kredit syariah di Indonesia. Bahwa adanya dampak negatif pada nasabah maupun bagi bank yang menerbitkannya yaitu: ${ }^{8}$ Kartu kredit syariah bisa mendorong nasabah untuk bersikap konsumtif, boros yang dilarang oleh ajaran agama Islam, dan salah satu misi utama bank syariah adalah mendorong terciptanya sektor riil yang banyak menyerap tenaga keja bukannya sebaliknya menciptakan umat yang konsumtif.

Kalau banyak kartu kredit syariah yang bermasalah misalnya pembayaran kartu kredit syariah banyak yang macet, hal ini bisa menggangu misi utama bank syariah dalam mendorong terciptanya sektor riil tersebut, serta kartu kredit syariah tidak dikenakan bunga keterlambatan dan tidak adanya jaminan (collateral) dari para nasabah penggunanya sehingga nasabah tidak ada ikatan moral maupun materiil untuk segera melakukan pembayaran tagihan kartu kredit syariahnya, sehingga nasabah cenderung melakukan penundaan pembayaran tagihan kartu kredit syariahnya. Hal ini bisa meningkatkan resiko Non Performing Financing (kredit bermasalah) di Bank Syariah yang menerbitkan kartu kredit syariah.
Masyarakat saat ini masih sangat awam dalam memahami kartu kredit syariah yang diterbitkan oleh perbankan Islam, masyarakat masih menyamakan kartu kredit syariah dengan kartu kredit yang diterbitkan bank konvensional. Oleh karena itu, menarik untuk dikaji lebih dalam mengenai salah satu produk pembiayaan ini.

Berdasarkan latar belakang yang peneliti kemukakan diatas, maka peneliti termotivasi untuk meneliti mengenai "Analisis Implementasi Kartu Kredit Syariah pada PT. Bank BNI Syariah cabang Palu (Perspektif Ekonomi Islam).

\section{TINJAUAN PUSTAKA}

\subsection{Penelitian Terdahulu}

Penelitian ini mengkaji tentang Analisis implementasi kartu kredit syariah pada PT. Bank BNI syariah cabang Palu yang dimaksud adalah Hasanah Card, dan perspektif ekonomi Islam. Sebagai analisis pembanding dalam penelitian ini, agar dapat diketahui signifikan antara penelitian terdahulu dengan penelitian yang akan dilakukan, baik secara teori dan lain sebagainya.

di Indonesia, Economic: Jurnal Ekonomi dan Hukum Islam, Vol. 5, No.1. 2015, 30. 
Penelitian Kurniawan Rahmadianto, (Universitas Brawijaya Malang 2013). ${ }^{9}$ Judul Kajian Kesyariahan Kartu Kredit Sayriah: Teori dan Realita, (studi pada Bank BNI Syariah Kota Malang). Tujuan dari penelitian ini untuk mengetahui bagaimana mekanisme perhitungan bagi hasil dari kertu kredit syariah (Hasanah Card), mekanisme akad dan pertanggung jawaban hukum syariah terhadap kartu kredit tersebut. Selanjutnya Tujuan lain untuk mengetahui apakah kartu kredit tersebut telah sesuai dengan azas-azas kesyariahan yang ada sehingga kartu kredit tersebut layak mendapatkan predikat kartu kredit syariah di dalam perbankan Islam di Indonesia yang merupakan suatu inovasi terbaru dan merupakan sebuah pilihan alternative bagi nasabah yang tidak menginginkan adanya riba' dalam tabungannya.

Penelitian ini menggunakan penelitian kualitatif dengan pendekatan fenomenologi. Dari hasil penelitian yang ditemukan, bahwa kartu kredit syariah ini belum memenuhi azas-azas kesyariahannya yang telah berlaku di Indonesia sendiri. Dalam mekanisme perhitungan fee, nasabah cenderung mengatakan bahwa perhitungannya tidak jauh berbeda antara konvensional dengan syariah. Hanya saja pada kartu kredit syariah bebas dari Annual fee dan lebih ringan jika dibandingkan dengan kartu kredit konvensional. Sedangkan dalam penggunaan akad, kartu kredit syariah menggunakan tiga akad yaitu kafalah, Qardh, dan Ijarah. Namun, dalam pembuatan akad kartu kredit syariah ini masih dilakukan secara sepihak oleh bank, seharusnya perjanjian itu disetujui oleh kedua belah pihak. Untuk penegakan hukum, masih sering terjadi kredit macet yang diakibatkan nasabah sering lupa membayar minimum payment-nya. Hal ini terjadi ksrena nasabah lebih condong untuk nerperilaku konsumtif. Namun dalam penyelesaiannya bank BNI syariah tidak menggunakan debt collector, tetapi lebih ke azas kekeluargaan dimana sifat hukum yang berlaku adalah elastis.

Persamaan dalam penelitian sebelumnya yaitu pada lokasi penelitian pada Bank BNI Syariah, yang berbeda hanya pada kota lokais penelitian. Selanjutnya, memiliki persamaan pada judul yaitu sama-sama mengangkat mengenai kartu kredit syariah akan tetapi berbeda pada apa yang ingin di teliti, pada penelitian sebelumnya lebih kepada teori dan realita dan penulis gunakan lebih kepada implementasinya. Peneliti ini menggunakan peneltian deskriptif atau pendekatan kualitatif.

Realita, (studi pada Bank BNI Syariah Kota Malang), Universitas Brawijaya, Malang, 2013. 
Penelitian Eka Rahmawati (UNISMUH Surakarta, 2006) ${ }^{10}$. Judul Studi Komparatif Kartu Kredit Konvensional Dengan Kartu Kredit Syariah. Penelitian ini menggunakan metode komparatif analitik, yaitu suatu metode dimana penulis mengumpulkan data, dijelaskan, dianalisa baru kemudian dibandingkan. Pendekatan yang diapakai adalah deskriptif analitis yaitu berusaha menjelaskan data yang telah dikumpulkan kemudian memberikan analisis berkaitan dengan hal tersebut dengan memakai pola pikir deduktif dan Induktif yaitu menganalisa pada kondisi yang bersifat khusus kemudian disusun rumusan yang bersifat umum atau sebaliknya.

Hasil penelitian ini menunjukkan bahwa sistem kerja kartu kredit konvensional dengan kartu kredit syariah terdapat beberapa perbedaan. Begitu juga jika dilihat dari sisi alur transaksinya kedua kartu tersebut juga memiliki banyak perbedaan. Pada kartu kredit konvensional, terdapat beberapa perjanjian seperti perjanjian jual beli, perjanjian kredit, perjanjian pemberian kuasa, dan perjanjian penjaminan perseorangan. Meskipun dalam kartu kredit syariah juga dapat ditemukan perjanjian yang sama, akan tetapi berbeda pada nama perjanjian dan sistemnya. Dalam kartu kredit syariah, beberapa perjanjian tersebut dikenal dengan beberapa akadnya, yaitu Akad wakalah, Akad kafalah, Akad bai', (jual beli/Tijaroh), ijaroh, hiwalah dan Qard.

Persamaan kedua kartu kredit ini yaitu keduanya sama-sama menguntungkan brerbagai pihak, karakter desainnya sama, mempunyai keuntungan dan resiko yang hampir sama, serta para pihak yang terlibat juga sama. Sedangkan perbedaannya kartu tersebut berada pada settlement/instrumen biaya, layanan/fasilitas yang nyata halal dan nilai ketuhanan/illahiyah yang mendarah daging.

Perbedaan dengan penelitian sebelumnya adalah penelitian ini membahas mengenai implementasi kartu kredit syariah yang ada di PT Bank BNI Syariah cabang Palu. Penelitian ini juga berbeda pada lokasi penelitian. Persamanya yaitu pada metode penelitian yang digunakan yaitu metode deskriptif atau kualitatif.

\subsection{Karakteristik Kartu Kredit Syariah}

Kartu kredit dalam kacamata hukum memiliki karakteristik sendiri, antara lain: Kartu kredit terdiri dari dua akad, yaitu transaksi financial dan akad kredit. Menurut Ms. De. Muth mengatakan, "Defininsi ini menunjukkan karakter kartu kredit adalah

\footnotetext{
${ }^{10}$ Eka Rahmawati, Studi Komparatif Kartu Kredit Konvensional Dengan Kartu Kredit Syariah, Universitas Muhammadiyah Surakarta, 2006.
} 
bahwa dalam kartu ini terdapat sifat-sifat akad transaksi dan sifat-sifat kredit. ${ }^{11}$

Kartu ini memiliki kelebihan dan keistimewaan yang tidak dimiliki oleh kartu lainnya, antara lain: ${ }^{12}$ Pertama, Kartu ini diaggap sebagai instrumen kredit yang hakiki, sebagai suatu hal yang menjadi pertimbangan dasar pembentukan akad antara Issuer bank dan card holder; Kedua, Bagi orang yang ingin mendapatkan kartu tersebut tidak diharuskan untuk memiliki rekening di bank Issuer Card; Ketiga, Pemegangnya tidak di tuntut untuk segera melunasi kreditnya, bahkan bisa dibayar selama waktu yang telah disepakati antara card holder dengan Issuer bank; Keempat, Pelunasan dilakukan dengan cara cicilan; dan kelima, Sebagian bank menerbitkan jenis kartu ini bagi nasabahnya tanpa melihat kepada pendapatan mereka.

Akan tetapi kartu kredit syariah juga bisa berdampak negative pada nasabah maupun bagi bank syariah yang menerbitkannya, yaitu: ${ }^{13}$ Kartu kredit syariah bisa mendorong nasabah untuk bersikap konsumtif, boros yang dilarang oleh ajaran agama Islam; salah satu misi utama bank syariah adalah mendorong terciptanya sektor riil yang

${ }^{11}$ Ibid, 48.

${ }^{12}$ Ibid, 49.

${ }^{13}$ Indah Nuhyatia, Kajian Fiqh dan Perkembangan Kartu Kredit Syariah (Syariah Card) banyak menyerap tenaga keja bukannya sebaliknya menciptakan ummat yang konsumtif. Kalau banyak kartu kredit syariah yang bermasalah misalnya pembayaran kartu kredit syariah banyak yang macet, hal ini bisa menggangu misi utama bank syariah dalam mendorong terciptanya sektor riil tersebut; kartu kredit syariah tidak dikenakan bunga keterlambatan dan tidak adanya jaminan (collateral) dari para nasabah penggunanya sehingga nasabah tidak ada ikatan moral maupun materiil untuk segera melakukan pembayaran tagihan kartu kredit syariahnya, sehingga nasabah cenderung melakukan penundaan pembayaran tagihan kartu kredit syariahnya. Hal ini bisa meningkatkan resiko Non Performing Financing (kredit bermasalah) di Bank Syariah yang menerbitkan kartu kredit syariah.

Adapun batasan-batasan dalam penggunaan kartu kredit syariah, yaitu ${ }^{14}$ : tidak menimbulkan riba, tidak digunakan untuk transaksi yang tidak sesuai dengan syariah, tidak mendorong pengeluaran yang berlebihan (israf), dengan cara antara lain menetapkan pagu maksimal pembelanjaan; pemegang kartu harus memiliki kemampuan

di Indonesia, Economic: Jurnal Ekonomi dan Hukum Islam, Vol. 5, No.1. 2015, 30.

${ }^{14}$ Fatwa DSN No. 54/DSN-

MUI/X/2006www.dsnmui.or.id, diakses pada 31-012017, jam 23:50. 
finansial untuk melunasi pada waktunya; dan tidak memberikan fasilitas yang tidak sesuai syariah.

Dalam Skripsi Widyanti Khaerudin, yang berjudul Analisis Sistem Kartu Kredit Syariah pada PT. Bank BNI Syariah. persamaan kartu kredit syariah dengan konvensional yaitu dari segi pengajuan/permohonan kartu kredit, seperti data-data pribadi, data pekerjaan, data keuangan, dan data kartu tambahan (jika pemohon mengajukan), dan juga proses yang dilakukan sama, yaitu dengan menagnalisa data pemohon yang telah ada, misalnya dengan mengacu pada aturan Bank Indonesia yaitu nama pemohon tidak tercantum dalam Daftar Hitam Nasional dan Asosiasi Kartu Kredit Indonesia (AKKI), pemohon memenuhi syarat administrative, memiliki alamat yang jelas dan nomor telepon yang dapat di hubungi, serta melihat sejarah dari kartu kredit lain yang dimiliki oleh pemohon. Output yang dihasilkan juga sama, yaitu kartu kredit yang mencantumkan nama pemohon (nama pemeilik kartu kredit ${ }^{15}$.

Adapun hal yang menjadi pembeda antara kartu kredit syariah dan kartu kerdit konvensional yakni: 1). Dasar hukum, yang menjadi dasar adalah Undang-undang Perbankan, Undang-undang perbankan syariah, dan Fatwa Dewan Pengawas Syariah Nasional. Sedangkan di bank konvensional dasar hukumnya hanya satu, yaitu Undang-undang Perbankan. 2). Penerbit, yang menjadi penerbit adalah bank Syariah, yaitu PT. Bank BNI Syariah, sedangkan yang menjadi penerbit kartu kredit konvensional adalah bank konvensional. 3). Perjanjian, perjanjian yang ada pada kartu kredit syariah berdasrkan akad Kafalah, Ijarah, dan qardh. Sedangkan pada kartu kredit konvensional, perjanjian yang digunakan berdasarkan pada bunga. 4). Ketentuan penggunaan, pada kartu kredit syariah penggunaannya dibatasi hanya untuk transaksi yang sesuai dengan syariah, sedangkan pada kartu kredit konvensional, penggunaannya tidak dibatasi. 5). Fitur-fitur yang digunakan dalam kredit syariah maupun konvensional adalah sama, yang membedakannya adalah penetapan fee-nya. 6). Pendapatan bank, pada bank syariah berasal dari annual fee, monthly fee, merchant fee, cash advance fee, dan sebagainya. Sedangkan pada kartu kredit konvenisonal adalah annual fee, bunga atas nominal transaksi, merchant fee, dan denda keterlambatan. 7). Cash collateral, dalam kartu kredit syariah, dibutuhkan untuk kartu Hasanah Card Classic, yaitu 10\% dari limit.

${ }^{15}$ Widyanti Khaeruddin, Analisis Kartu Kredit Syariah pada PT. Bank BNI Syariah, Skripsi, 2012. 57. 
Hal ini diperlukan karena melihat dari pengalaman yang ada bahwa melihat dari pengawalaman bahwa sebagian besar kartu bermsalah adalah dari jenis kartu gold ke bawah atau dengan kata lain classic. Sedangkan dalam konvensional cash collateral tidak diperlukan.

\section{METHODOLOGY}

Penelitian ini menggunakan pendekatan kualitatif dengan mengambil lokasi penelitian di PT. Bank BNI Syariah Cabang Palu. Dengan Alamat J1. Jenderal Sudirman No. 7, Kec. Palu Timur, Kota Palu, Sulawesi Tengah. Alasan peulis melakukan penelitian di PT Bank BNI Syariah Cabang Palu, dengan pertimbangan saat ini Bank BNI Syariah satu-satunya Bank Syariah yang berada di kota Palu menerapkan Kartu Kredit Syariah, berdasarkan hasil observasi di Bank BNI Syariah cabang Palu.

Data dikumpul melalui teknik observasi, wawancara mendalam, dan dari berbagai dokumen yang ada. Setelah sejumlah data dan keterangan penulis dikumpulkan, maka langkah selanjutnya adalah menganalisi data. Adapun teknik analisi data yang digunakan dalam penelitian ini adalah : Reduksi Data, yaitu penulis merangkum beberapa data yang ada di lapangan,

\footnotetext{
${ }^{16}$ Moleong, Metode, 184.
}

kemudian mengambil dari beberapa data yang dianggap mewakili untuk dimasukan dalam pembahasan ini. ${ }^{16}$ Penyajian data, yaitu menyajikan data yang telah direduksi dalam model-model tertentu untuk menghindari adanya kesalahan penafsiran terhadap data tersebut. Selanjutnya dilakukan verifikasi data, yaitu adanya suatu pengambilan kesimpulan yang dilakukan oleh peneliti terhadap data tersebut.

\section{HASIL DAN PEMBAHASAN}

\subsection{Gambaran Lokasi Penelitian}

Tempaan krisis moneter tahun 1997 membuktikan ketangguhan sistem perbankan syariah. Prinsip Syariah dengan 3 (tiga) pilarnya yaitu adil, transparan dan maslahat mampu menjawab kebutuhan masyarakat terhadap sistem perbankan yang lebih adil. Dengan berlandaskan pada Undang-undang No.10 Tahun 1998, pada tanggal tanggal 29 April 2000 didirikan Unit Usaha Syariah (UUS) BNI dengan 5 kantor cabang di Yogyakarta, Malang, Pekalongan, Jepara dan Banjarmasin. Selanjutnya UUS BNI terus berkembang menjadi 28 Kantor Cabang dan 31 Kantor Cabang Pembantu ${ }^{17}$.

Disamping itu nasabah juga dapat menikmati layanan syariah di Kantor Cabang BNI Konvensional (office channelling)

${ }^{17}$ www.bnisyariah.co.id, diakses pada 1 Februari 2017 jam 14:55. 
dengan lebih kurang 1500 outlet yang tersebar di seluruh wilayah Indonesia. Di dalam pelaksanaan operasional perbankan, BNI Syariah tetap memperhatikan kepatuhan terhadap aspek syariah. Dengan Dewan Pengawas Syariah (DPS) yang saat ini diketuai oleh KH.Ma'ruf Amin, semua produk BNI Syariah telah melalui pengujian dari DPS sehingga telah memenuhi aturan syariah.

Berdasarkan Keputusan Gubernur Bank Indonesia Nomor 12/41/KEP.GBI/2010 tanggal 21 Mei 2010 mengenai pemberian izin usaha kepada PT Bank BNI Syariah. Dan di dalam Corporate Plan UUS BNI tahun 2003 ditetapkan bahwa status UUS bersifat temporer dan akan dilakukan spin off tahun 2009. Rencana tersebut terlaksana pada tanggal 19 Juni 2010 dengan beroperasinya BNI Syariah sebagai Bank Umum Syariah (BUS). Realisasi waktu spin off bulan Juni 2010 tidak terlepas dari faktor eksternal berupa aspek regulasi yang kondusif yaitu dengan diterbitkannya UU No.19 tahun 2008 tentang Surat Berharga Syariah Negara (SBSN) dan UU No.21 tahun 2008 tentang Perbankan Syariah. Disamping itu, komitmen Pemerintah terhadap pengembangan perbankan syariah semakin kuat dan kesadaran terhadap keunggulan produk perbankan syariah juga semakin meningkat. Juni 2014 jumlah cabang BNI Syariah mencapai 65 Kantor Cabang, 161 Kantor Cabang Pembantu, 17 Kantor Kas, 22 Mobil Layanan Gerak dan 20 Payment Point $^{18}$.

Kartu kredit syariah di keluarkan oleh PT. Bank BNI Syariah didasarkan pada fatwa Dewan Syariah Nasional (DSN) No.54/DSN-MUI/X/2006 mengenai Syaruiah Card dan surat persetujuan dari Bank Inonesia, No. 10/337/DPbs tanggal 1103-2008.

Kartu kredit syariah atau biasa disebut dengan Hasanah Card di terbitkan pada tahun 2009. Walaupun kartu krdit syariah ini belum lama beredar tapi kartu kredit syariah ini sudah memperoleh penghargaan, yaitu pelopor kartu kredit pertama yang hanya bisa bertransaksi di gerai halal dan sebagai kertu kreddit pertama yang meinginspirasi berwirausaha.

\subsection{Implementasi Kartu Kredit Dalam Perspektif Ekonomi Islam}

Dalam implementasi kartu kredit syariah, PT Bank BNI Syariah menerapkannya berdasarkan Fatwa Dewan Syariah Nasional Majelis Ulama Indonesia (DSN-MUI) No.54/DSN-MUI/X/2006 mengenai ketentuan syariah card yang di maksud adalah: 


\section{Ketentuan Akad ${ }^{19}$}

Kafalah : Penerbitan kartu adalah penjamin (kahfi) bagi pemegang kartu terhadap merchant atas semua kewajiban bayar (dayn) yang timbul dan atau penarikan uang tunai selain Bank atau ATM Bank Penerbit Kartu. Atas pemberian Kafalah, penerbit kartu dapat menerima fee (ujrah).

Qard : Penerbit kartu adalah pemberi jaminan (muqridh) kepada pemegang kartu (muqtaridh) melalui penarikan tunai dari Bank atau ATM Bank Penerbit Kartu.

Ijarah : Penerbit kartu adalah penyedia jasa sistem pembayaran dan pelayanan terhadap pemegang kartu. Atas Ijarah ini, pemegang kartu dikenakan Membership fee.

\section{a. Akad Kafalah}

Kafalah menurut bahasa berarti alDhaman (Jaminan), hamalah (beban), dan $z a$ 'amah (tanggungan $)^{20}$. Sedangkan menurut istilah yang dimaksud dengan kafalah atau al-Dhaman sebagaimana dijelaskan oleh para ulama adalah sebagai berikut:

${ }^{19}$ Fatwa Dewan Syariah Nasional Majelis Ulama Indonesia (DSN-MUI) No.54/DSNMUI/X/2006

${ }^{20}$ Dwi Swiknyo, Ayat-ayat Ekonomi, Pustaka Pelajar: Yogyakarta, cet. 2010. 134. a. Menurut Mazhab Hanafi bahwa Kafalah memiliki dua pengertian, yang pertama, arti Kafalah ialah menggabungkan dzimah kepada dzimah yang lain kedalam penagihan, dengan jiwa, uatang atau zat benda. Arti kafalah yang kedua ialah menggbungkan dzimah dalam pokok asal utang ${ }^{21}$.

b. Menurut Mazhab Maliki bahwa kafalah ialah orang yang berhak mengerjakan tanggungan pemberi beban serta bebannya sendiri yang disatukan, baik menanggung pekerjaan yang sesuai (sama) maupun pekerjaan yang berbeda $^{22}$.

c. Menurut Mazhab Hanbali bahwa yang dimaksud dengan kafalah adalah Iltizam sesuatu yang diwajibkan kepada orang lain serta kedekatan denda tersebut yang dibebankan atau Iltizam orang yang mempunyai hak menghadirkan dua harta (pemiliknya) kepada orang yang mempunyai hak menghadirkan dua harta (pemiliknya) kepada orang yang mempunyai hak ${ }^{23}$.

d. Menurut Mazhab Syafi'I bahwa yang dimaksud dengan kafalah ialah Akad

\footnotetext{
${ }^{21}$ Abdurrahman Al-Jaziri, Al-Fiah 'ala
}

Madzahib al'Arba'ah, 221.

${ }^{22}$ Ibid, 223.

${ }^{23}$ Ibid, 224. 
yang menetapkan Iltizam hak yang tetap pada tanggungan (beban) yang lain atau menghadirkan zat beban yang dibebankan atau menghadirkan badan oleh yang berhak menghadirkan ${ }^{24}$. Berdasarkan definisi yang dikemukakan oleh Mazhab Syafi' I di atas bahwa kafalah terdiri atas tiga pengertian, yaitu: al-kafalah al-Dayn, al-Kafalah al-'Ain dan al-Kafalah alAbdan.

e. Menurut Sayyid Sabiq yang dimaksud dengan kafalah ialah proses penggabungan tanggungan kafil menjadi beban ashil dalam tuntutan dengan benda (materi) yang sama, baik utang, barang maupun pekerjaan.

f. Menurut Imam Taqiy al-Din bahwa yang dimaksud dengan kafalah adalah mengumpulkan satu beban kepada beban lain.

g. Menurut Hasbi ash-Shiddiqie bahwa yang dimaksud dengan Kafalah ialah menggabungkan dzimah kepada dzimah lain dalam penagihan.

\section{Ketentuan $\mathrm{Fe}^{25}$}

a. Iuran keanggotaan (membership fee), penerbit kartu berhak menerima iuran keanggotaan (rusum al-'udwiyah) termasuk perpanjangan masa

\footnotetext{
${ }^{24}$ Ibid, 225.

${ }^{25}$ Fatwa Dewan Syariah Nasional Majelis Ulama Indonesia (DSN-MUI) No.54/DSNMUI/X/2006
}

keanggotaan dari pemegang Kartu sebagai imbalan (Ujrah) atas izin penggunaan fasilitas kartu.

b. Merchant fee, penerbit kartu boleh menerima fee yang diambil dari harga objek transaksi atau pelayanan sebagai upah/imbalan (ujrah) atas perantara (samsarah), pemasaran (taswiq) dan penagihan (tahsil al-dayn).

c. Fee penarikan uang tunai, penerbit kartu boleh menerima fee penarikan uang tunai (rusum sahb al-nuqud) sebagai fee atas pelayanan dan penggunaan fasilitas yang besarnya tidak dikaitkan dengan jumlah penarikan.

d. Fee Kafalah, penerbit kartu boleh menerima fee dari pemegang kartu atas pemberian Kafalah.

Semua bentuk fee tersebut di atas (a-b-cd) harus ditetapkan pada saat akad aplikasi kartu secara jelasdan tetap, kecuali untuk merchant fee.

\section{Batasan (Dhawabith wa Hudud) Kartu Kredit Syariah ${ }^{26}$}

a. Tidak menimbulkan riba.

b. Tidak digunakan untuk transaksi yang tidak sesuai dengan syariah.

c. Tidak mendorong pengeluaran yang berlebihan (Israf), dengan cara antara

${ }^{26}$ Fatwa Dewan Syariah Nasional Majelis Ulama Indonesia (DSN-MUI) No.54/DSNMUI/X/2006 
lain menetapakan pagu maksimal. dengan cara antara lain menetapakan pagu maksimal.

d. Pemegang kartu harus memiliki kemampuan financial untuk melunasi pada waktunya.

e. Tidak memberikan fasilitas yang bertentangan dengan syariah.

\section{Ketentuan Ta'widh dan Denda ${ }^{27}$}

a. Penerbit kartu dapat mengenakan ta'widh, yaitu ganti rugi terhadap biayabiaya yang dikenakan oleh Penerbit kartu akibat keterlambatan pemegang kartu dalam membayar kewajibannya yang telah jatuh tempo.

b. Denda keterlambatan (late charge) Penerbit kartu dapat mengenakan denda keterlambatan pembayaran yang akan diakui seluruhnya sebagai dana sosial.

\section{Ketentuan Tertutup ${ }^{28}$}

Jika salah satu pihak tidak menunaikan kewajibannya atau jika terjadi perselisihan antara pihak-pihak terkait, maka penyelesaiannya dapat dilakukan melalui Badan Arbitrase Syari'ah atau melalui Pengadilan Agama salehah tidak tercapai kesepakatan melalui musyawarah.

\section{Analisis}

Impelementasi kartu kredit syariah yang ada pada PT. Bank BNI Syariah cabang Palu telah sesuai dengan ketetapan ekonomi islam dengan tidak menimbulkan riba karena tidak ada unsur kezhaliman di dalamnya, dan juga transparan dalam mnentukan kesepakatan.

Menurut saya akad dan batasan yang ada pada PT. Bank BNI Syariah cabang Palu telah sesuia dengan ketetapan ekonomi islam yang dibuat oleh mui yaitu:

a. batasan kartu kredit syariah yabg ada pad apt bank bni syariah.

1. Tidak digunakan untuk transaksi yang tidak sesuai dengan syariah.

2. Tidak mendorong pengeluaran yang berlebihan (israf).

3. Pemegang kartu kredit syariah harus memiliki kemampuan financial untuk melunasi pada waktunya.

b. batasan kartu kredit syariah yang ditetapman oleh mui.

1.Tidak menimbulkan riba.

2.Tidak digunakan untuk transaksi yang tidak sesuai dengan syariah.

3.Tidak mendorong pengeluaran yang berlebihan (Israf), dengan cara antara lain menetapakan pagu maksimal. dengan cara antara lain menetapakan pagu maksimal.

4.Pemegang kartu harus memiliki kemampuan financial untuk melunasi pada waktunya.

\footnotetext{
${ }^{27}$ Fatwa Dewan Syariah Nasional Majelis Ulama Indonesia (DSN-MUI) No.54/DSNMUI/X/2006
}

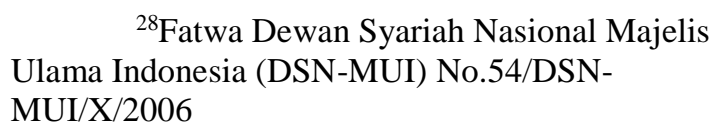


Tidak memberikan fasilitas yang bertentangan dengan syariah.

\section{KESIMPULAN DAN SARAN}

Impelentasi Kertu Kredit Syariah yang ada pada PT. Bank BNI Syariah cabang Palu telah sesuai dengan perspektif ekonomi islam, mulai dari proses penerbitan hingga disetujuinya. Hal ini berdasarkan batasan kartu kredit syariah. Dalam implementasi kartu kredit syariah yang ada pada PT Bank BNI Syariah cabang palu, menutup rapat resiko yang akan menimbulkan adanya riba dengan cara menutup sementara kartu kredit syariah yang digunakan nasabah secara sementra sampai akhirnya dilunasi oleh nasabah yang bersangkutan. secara otomatis dalam penggunaan kartu kredit akan terdeteksi dan tidak dapat diguanakan dalam transaksi yang tidak sesuai dengan syariah, seperti membelanjakannya untuk pembelian alkohol, daging babi dan ditempat hiburan malam dan lain sebagainya.

Dalam kartu kredit syariah yang ada pada PT. Bank BNI Syariah sudah ditetapkan limit/batas penggunaan kartu kredit syariah berdasarkan jenis kartu yang digunakan oleh nasabah. Pada PT. Bank BNI Syariah cabang Palu, telah menetapkan bahwa salah satu syarat utama dalam menerbitkan kartu kredit syariah harus memiliki kemampuan finansial, dan standarnya berdasarkan jenis 
Bambang Prasetyo dan Lina Miftahul Jannah, Metode Penelitian Kualitatif, Jakarta: PT Raja Grafindo Persada, 2005.

Caroline, Penerapan Kartu Kredit Syariah dan Perlindungan Nasabah di Bank BNI Syariah, Universitas Indonesia, Jakarta, 2010.

Dewi Sukma Kristianti, Kartu Kredit Syariah dan Perilaku Konsumtif Masyarakat, Jurnal Ahkam: Vol. XIV, No. 2, Juli 2014.

Eka Rahmawati, Studi Komparatif Kartu Kredit Konvensional Dengan Kartu Kredit Syariah, Universitas Muhammadiyah Surakarta, 2006.

Fatwa DSN No. 54/DSN-MUI/X/2006, www.dsnmui.or.id, diakses pada 3101-2017, jam 23:50.

http://id.m.wikipedia.org/wiki/penelitian_deskri ptif. Diakses pada 01-Februari-2017, jam 15:58

http://id.m.wikipedia.org/wiki/Bank_Negara_Indonesia. Diakses pada 1 Februari 2017, jam 14;21.

http://id.m.wikipedia.org/wiki/Perspektif. Diakses pada 1 Februari 2017, jam 14;32. http://id.m.wikipedia.org/wiki/Ekonomi_Islam. Diakses pada 1 Februari 2017, jam 14;41.

Indah Nuhyatia, Kajian Fiqh dan Perkembangan Kartu Kredit Syariah (Syariah Card) di Indonesia, Economic: Jurnal Ekonomi dan Hukum Islam, Vol. 5, No.1. 2015

Kamus Besar Bahasa Indonesia, Analisis (Aplikasi).

Kamus Besar Bahasa Indonesia, Implementasi (Aplikasi).
Pusat Pengkajian dan Pengembangan Ekonomi Islam (P3EI) UII Yogyakarta, bekerja sama dengan Bank Indonesia, Ekonomi Islam, Jakarta: PT.RajaGrafindo Persada, 2008.

Rozalinda, Ekonomi Islam (Teori dan Aplikasi pada Aktivitas Ekonomi), Jakarta: PT.RajaGrafindo Persada, 2015

Risna Sulistyawaty, Perilaku Konsumen dalam Penggunaan Kartu Kredit di Wilayah DKI Jakarta, Artikel.

Reni Widya Astari, https://kreditgogo.com/artikel/Kartukredit/keuntungan-memiliki-kartukredit-syariah.html.

Santoso dan Sulhadi, Periodisasi Perkembangan Hukum Perbankan Syariah di Indonesia, Yudisia, Vol.6, No. 1, Juni 2015.

Suwiknyo, Dwi, (Kompilasi Tafsir) AyatAyat Eknomi Islam,Cet. I Yogyakarta: Pustaka Pelajar, 2010.

S.Margono, Metodologi Penelitian Pendidikan, Cet. II ,Jakarta: Rineka Cipta, 2000.

Sutrisno hadi, Metodologi Research Jilid I, Cet. 50; Yogyakarta: Andi Yogyakarta, 2002. www.suduthukum.com. Dia kses pada 1 Februari 2017, jam 14:55. 